\section{Gaya Hidup Beragama Komunitas Hijabers di Kota Padang}

\section{Elzi Wardani}

UIN Imam Bonjol Padang, Sumatera Barat, Indonesia elziwardani09@yahoo.com
Indonesian Journal of Religion and Society, 2019, Vol. 01 (01), 24-37

(C) The Journal, 2019

www.journal.lasigo.org/index.php/IJRS

Layis Journal

Article History

Received : March, $3^{\text {rd }} 2019$

Revised: Mei, $7^{\text {th }} 2019$

Accepted : Mei $9^{\text {th }} 2019$

\begin{abstract}
The veil for women in Indonesia seems to come across a new phase. Veil is no longer considered an ancient one, but a modernization to keep up with the times. The emergence of a variety of improper hijabers communities was a form of the high interest of veil. This study is aim to examine and explore the process of the community and the discovery between religion and lifestyle and the factor of the establishment of the community. This study conducted through qualitative with interviews as data collection techniques. Data analized through reduction, display, ferivication and interpretation. The result show; first, the factor in the formation of the hijabers community is religion broadcast, invited inspiring women and a place to share experiences. Second, the activities of the hijabers community are related to religion and moslem women livestyle, such as regular recitation, seminars, and sharing experiences. There are yearly activities that is is combination of all activities carried out by hijabers community. Third, the religious practices of the hijabers community are expression of their religious lifestyle in the public. In addition, it was also found that this community has a business mission with a hijab as a media.
\end{abstract}

Keywords: hijaber community; lifestyle, religion

\begin{abstract}
ABSTRAK
Penggunaan jilbab bagi perempuan Indonesia seakan menemui fase baru saat ini. Berjilbab bukan lagi dianggap sebagai kuno, melainkan gaya modern untuk mengikuti perkembangan zaman. Munculnya berbagai komunitas jilababer di berbagai kota merupakan representasi tingginya peminat jilbab. Dengan mengambil Kota Padang sebagai kasus, studi ini bertujuan untuk melihat proses terbentuknya komunitas hijaber serta cara komunitas mempertemukan antara agama dan gaya hidup (fashion). Penelitian dilakukan secara kualitatif dengan teknik pengumpulan melalui wawancara. Analisis data dilakukan melalui tahapan reduksi, penyajian, ferivikasi dan penarikan kesimpulan. Hasil penelitian menunjukkan bahwa faktor pendorong terbentuknya komunitas hijaber adalah untuk mensyiarkan agama, mengajak perempuan ikut memakai hijab, serta menjadi wadah dalam berbagi pengalaman. Kedua, kegiatan komunitas hijabers selalu berhubungan dengan kegiatan kegamaan dan kecantikan, seperti pengajian bulanan, seminar dan sharing pengalaman. Terdapat juga kegiatan tahunan yang merupakan gabungan seluruh kegiatan komunitas hijaber. Ketiga, praktik keagamaan komunitas hijabers termanifestasi dari cara mengekspresikan gaya hidup beragama di ruang publik. Selain itu juga ditemukan misis usaha/bisnis bermotif hijab.
\end{abstract}

Kata Kunci: komunitas hijaber; gaya hidup; agama

Corresponding Author

Name: Elzi Wardani

Email: elziwardani09@yahoo.com 


\section{Pendahuluan}

Perkembangan komunitas jilbaber memiliki daya tarik tersendiri untuk diteliti. Hal ini ditandai dengan bermunculan berbagai komunitas jilbaber dengan berbagai gaya jilbab yang digunakan. Diawali dengan komunikasi melalui media sosial dan berbagi wacana, mendorong kalangan perempuan untuk kembali ke trah untuk berjilbab namun lebih modern. Tidak sebatas itu, berjilbab juga mendorong mereka untuk membentuk komunitas untuk berbagai ilmu pengetahuan. Adanya komunitas jilbaber memudahkan untuk mengikuti perkembangan dan gaya berjilbab kekinian. Gaya berjilbab yang dulunya dikenal monoton, sekarang mengikuti trend. Gaya berjilbab dimodifikasi sedemikian rupa sehingga mampu menarik perhatian publik, khususnya kalangan perempuan. Salah satu pencetus komunitas gaya berjilbab yang dikenal dengan Jilbabers Community adalah sekelompok perempuan muda yang berasal dari Jakarta antara lain Ria Miranda dan Dian Pelangi pada Maret 2011. Semangat awal berdirinya Jilbabers Community adalah mengajak kaum perempuan untuk berjilbab dengan penampilan modern. Dengan demikian, komunitas jilbaber menjadi wadah khusus bagi perempuan untuk termotivasi memakai jilbab. Melalui komunitas, para anggota yang terhimpun dapat melakukan diskusi dengan berbagai ilmu, pengalaman, dan bahkan gaya hidup kekinian fashion ala Islami (Sari, 2016).

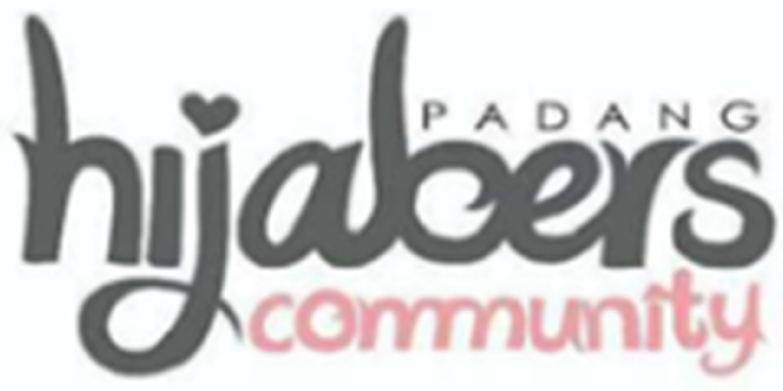

Gambar 1. Logo Hijabers Community Kota Padang

Tidak bisa dipungkiri, bahwa semakin tinggi pertumbuhan ekonomi dan pendapatan seseorang akan berdampak terhadap kebutuhan hidup. Salah satunya adalah kebutuhan dalam gaya hidup dan penampilan yang mesti dipenuhi (Yasin, 2015). Seperti yang dijelaskan oleh Kotler dan Amstrong, gaya hidup merupakan pola seseorang di dunia yang dapat diungkapkan melalui aktifitas, minat dan opininya (Kotler \& Amstrong, 2008). Hal tersebut dapat dilihat melalui penampilan seseorang. Salah satu yang dapat dilihat adalah melalui pakaian yang di gunakan dalam keseharian. Saat ini, pakaian yang paling tren adalah berpakaian gamis dan berjilbab. Seakan menjadi trending kekinian, berjilbab menjadi sesuatu yang dibutuhkan oleh kaum perempuan. Tidak hanya itu, berjilbab yang dulunya dianggap suatu yang kuno, sekarang justru berbanding terbalik. Perempuan tidak berjilbab justru dianggap tidak mengikuti perkembangan zaman modern. Dapat dipahami, bahwa ada rasa kepuasan tersendiri bagi kalangan perempuan ketika berjilbab. Berjilbab seakan menjadi daya tarik tersendiri bagi orang lain serta lebih merasa Islami secara keagamaan. Hal tersebut seakan melatarbelakangi munculnya fenomena berjilbab secara berjamaah. Dengan adanya daya tarik bagi orang lain, keikutsertaan orang lain dalam gaya jilbab seakan memiliki kepuasan batin bagi kelompok jilbabers tersebut. Tidak hanya sebatas perhatian namun penampilan yang ditunjukkan sudah merupakan sensasi (sensation seeking) yang perlu diakui dan di ekspos di berbagai media sosial (Ramadhini, 2017).

Gaya hidup mampu membentuk tujuan bersama melalui sekelompok orang atau individu yang memiliki perilaku berbeda. Hal tersebut dapat dilihat ketika berada pada tempat yang sama, maka akan memiliki tujuan yang sama. Sehingga perilaku yang terlihat 
dari gaya hidup tersebut merupakan campuran dari kebiasaan yang sudah disepakati secara bersama untuk dilakukan sesuai rencana. Jika dikonsepsikan, manusia merupakan hasil dari beberapa pengalaman serta interaksi dari lingkungannya. Dengan kata lain, perilaku tersebut merupakan reaksi seseorang terhadap dorongan maupun rangsangan baik dari luar ataupun dari dalam diri seseorang (Notoatmodjo, 2003). Demikian halnya dengan komunitas jilbabers. Pada dasarnya mereka berasal dari lingkungan berbeda dan kehidupan sosial yang berbeda. Namun tetap saja, ketika latarbelakang yang berbeda tersebut terhimpun dalam suatu komunitas akan membentuk tujuan yang sama. Kesepakatan semacam ini seakan dapat mempengaruhi lingkungan yang lebih besar seperti terbentuk berbagai komunitas termasuk komunitas di Kota Padang.

Dampak ini seakan menimbulkan kecenderungan baru terhadap kebutuhan gaya hidup bagi kalangan perempuan. Melalui studi yang dikemukan oleh Rhamadini (2017) bahwa berjilbab tidak lagi sebagai suatu yang di anggap kewajiban secara keagamaan melainkan juga sudah bergeser terhadap gaya hidup (fashion) seseorang. Berhijab bukan lagi suatu yang kaku. Selain itu, ia berpendapat bahwa dengan banyaknya peminat dari berbagai kota, juga menguntungkan bagi seseorang dengan memanfaatkan media sosial. Seseorang juga dikenal dan bahkan juga akan terkenal layaknya seorang artis. Hal ini yang menjadi motivasi bagi kelompok jilbabers tersebut. Dari sisi pergaulan misalnya, mereka juga mendapatkan teman baru, teman curhat baru, dan lain sebagainya. Sehingga kegiatan yang direncanakan akan terlaksana dengan nyaman.

Fenomena hijab sebagai gaya hidup menarik dilihat dalam kacamatan sosial keagamaan yang berkembang di tengah masyrakat modern. Berbagai studi yang dilakukan antara lain oleh Nurul Fadhila Fachri (2013), Riskiyana Ulfa, dkk (2014), Yolla Miftahul Huda (2014), masih mendiskusikan jilbab pada tataran material. Meskipun salah satu penelitian yang dikemukakan oleh Weni Anggraini (2016), hampir mendekati penelitian yang penulis lakukan, namun masih terdapat ruang kosong yang mesti dilakukan kajian lebih lanjut. Studi ini lebih berfokus pada faktor yang melatar belakangi berdirinya komunitas hijabers Kota Padang. Apa saja kegiatan sosial keagamaan dari komunitas hijabers Kota Padang? Bagaimana praktek keagamaan dari komunitas hijabers Kota Padang? Pertanyaan ini muncul karena penggunaan jilbab tidak hanya sebatas motif Islam bagi kalangan perempuan dewasa. Namun mesti dilihat dari kecenderungan yang mempengaruhi kenapa munculnya komunitas yang mengarahkan pemahaman tertentu namun bersifat modern. Gaya jilbab modernisasi inilah yang menjadi ruang baru yang harus dilakukan kajian ulang. Penelitian fokus terhadap faktor dan dorongan yang membuat perempuan membentuk komunitas. Sehingga komunitas yang terbentuk mesti dilihat kencenderungan dari kajian yang pernah diteliti Andriani dan Ni'matuzahroh (2013).

\section{Kerangka Teori}

Berjilbab dapat diasumsikan sebagai identitas bagi seorang muslim dalam kehidupan beragam. Dalam kehidupan sosial, berjilbab menandai ketaatan seseorang dalam menjalani ibadah. Identitas sosial menurut Tajfel dapat diartikan dalam bentuk konsep diri secara individu yang terbangun dari keanggotaannya dalam suatu kelompok sosial yang terkadung nilai yang signifikansi serta emosionalnya yang melekat dalam keanggotaan tersebut (Tajfel, 1974). Menurut Tajfel ada tiga proses dasar terbentuknya identitas sosial, 1) identifikasi sosial, 2) kategorisasi sosial dan 3) perbandingan sosial. Selain itu G. H. Mead menggambarkan bahwa identitas dari diri seseorang berasal dari sudut pandang kelompok sosial. Namun Mead lebih menekankan bahwa kelompok dapat mempengaruhi hal yang penting bagi seseorang dikarenakan setiap anggota akan menjalankan perannya masing- masing sehingga dengan mudah dapat berinteraksi dengan orang lain (Ritzer \& Goodman, 2010).

Selain itu, jilbab merupakan representasi simbolik bagi seseorang atau individu terhadap orang lain. Dengan demikian akan mempermudah dalam berinteraksi dengan masyarakat. George Herbert Mead (Ritzer \& Goodman, 2010) berpandangan bahwa, dalam masyarakat terdapat simbol-simbol yang saling memengaruhi dan berinteraksi secara 
sosial. Simbol tersebut seringkali digunakan sebagai sesuatu yang dapat direpresentasikan. Selain itu, simbol juga digunakan oleh individu untuk memberitahukan sesuatu tentang dirinya sendiri kepada khalayak. Mead memaparkan bahwa realitas sosial merupakan proses yang berlangsung terus-menerus dan bukan sesuatu yang statis. Manusia pada dasarnya memiliki persepsi (mind) dalam mengartikan dirinya (self) dengan interaksinya bersama orang lain atau masyarakatnya (society) (Ritzer \& Goodman, 2010).

Mengandaikan bahwa jilbab merupakan identitas yang berkaitan erat dari individu dalam kehidupan sosial, tentu juga tidak bisa dipisahkan dari gaya hidup dalam masyarakat. Gaya hidup inilah yang secara terus menerus membentuk interaksi baik secara individu, maupun secara kelompok (Tahir \& Triantini, 2014). Gaya hidup menurut Kotler dan Amstrong adalah pola hidup seseorang dalam dunia kehidupan sehari-hari yang dinyatakan dalam kegiatan, minat dan pendapat yang bersangkutan (Kotler \& Amstrong, 2008). Gaya hidup sering digambarkan dengan kegiatan, minat dan opini dari seseorang (activities, interests, and opinions). Gaya hidup seseorang biasanya tidak permanen dan cepat berubah. Seseorang mungkin dengan cepat mengganti model dan merek pakaiannya karena menyesuakan dengan perubahan hidupnya (Sumarwan, 2004).

Gaya hidup menunjukkan bagaimana orang mengatur kehidupan pribadinya, kehidupan masyarakat, perilaku di depan umum, dan upaya membedakan statusnya dari orang lain melalui lambang-lambang sosial (Notoatmodjo, 2003). Gaya hidup atau life style dapat diartikan juga sebagai segala sesuatu yang memiliki karakteristik, kekhususan, dan tata cara dalam kehidupan suatu masyarakat tertentu (Noer, 2016).

\section{Metode Penelitian}

Penelitian ini menggunakan metode kualitatif dengan pendekatan fenomenologis. perspektif fenomenologis memandang perilaku manusia; apa yang dilakukan, disepakati dan bagaimana tafsir dari kesepakatan yang mereka lakukan. Dengan demikian, peneliti harus menangkap serta memperhartikan proses-proses tersebut melalui pemahaman serta "empati merasa dalam diri orang lain" (Sutopo, 2006). Selain itu, peneliti juga melakukan wawancara secara mendalam dengan beberapa informan yang merupakan pendiri dari komunitas hijabers di Kota Padang. Informan terdiri dari dua tipe, pertama adalah dari informan yang menggunakan jilbab sekaligus merupakan bagian dari komunitas. Kedua adalah ustadzah sebagai informan yang mengisi materi pengajian yang dibentuk oleh komunitas hijabers. Meskipun demikian, tahap pertama yang peneliti lakukan adalah observasi lapangan untuk melihat fenomena serta gejala yang terjadi dilapangan. Setelah menemukan objek kajian penelitian, maka peneliti melakukan pembagian tipe informan sebelum dilakukan wawancara dengan informan. Ini merupakan upaya dalam rangka menemukan suatu temuan yang baru dari penelitian yang telah dilakukan sebelumnya. Seperti yang dijelaskan oleh Sugiyono (2005) bahwa penarikan suatu kesimpulan merupakan suatu temuan yang baru dari yang telah di teliti.

\section{Kehidupan Sosial dan Praktik Keagamaan Komunitas Hijabers Di Kota Padang}

Kemunculan komunitas jilbabers di Kota Padang adalah bentuk gaya baru berbusana muslimah sebagai sebuah tren bagi kalangan perempuan. Tren tersebut berkembang lebih kepada dress code. Dress code merupakan cara berbusana bagi perempuan dalam memilih warna yang sesuai antara jilbab, gamis, serta asessories yang digunakannya. Meskipun tidak selalu sama antara pasangan jilbab yang digunakan dengan gamisnya, namun kecenderungan tetap menyerupai. Selain itu, dress code tersebut juga berkaitan erat dengan media sosial yang sering mereka gunakan dalam mengonsumsi fashion seperti: Instagram dan Facebook. Sebagaimana yang diketahui bahwa kehidupan wanita yang tergabung dalam komunitas tersebut terdiri dari kalangan menengah atas. Hal tersebut diungkapkan salah satu informan bahwa hampir rata-rata wanita yang dalam komunitas tersebut memiliki usaha sendiri dan bisnis. Dengan demikian, kehidupan sosial membuat kaum wanita tersebut memiliki motivasi dan design dalam pertemuan layaknya arisan. Namun, tetap saja dalam pertemuan yang diadakan oleh komunitas tersebut tidak menyinggung persoalan bisnisnya masing-masing, dengan arti kata tetap fokus terhadap pengajian dan persoalan keagamaan dan gaya hijab. 


\subsection{Kehidupan Sosial Komunitas Hijabers di Kota Padang}

Dapat dicermati bahwa budaya jilbabers merupakan kebutuhan yang sangat dominan bagi kaum wanita dewasa ini. Sebagaimana yang telah diulas bahwa jilbaber tidak hanya menjadi bagian dari sisi keagamaan, tapi juga bagian yang penting dalam gaya hidup dan ekonomi masyarakat. Sehingga dapat dipahami bahwa poin penting dari komunitas jilbabers Kota Padang adalah dalam rangka mendobrak popularitas dalam bidang usaha. Melalui salah seorang informan menjelaskan:

"Pada saat berkumpul dengan komunitas kita semua tidak pernah membahas tentang bisnis. Meskipun banyak bisnis pada komunitas ini, bisnis tersebut hanya bersifat pribadi" (Agma,wawancara 25 Mei 2017).

Dari penjelasan diatas dapat dipahami bahwa perempuan yang tergabung dalam komunitas hijabers secara tidak langsung memisahkan diri antara bisnis dan kehidupan keagamaan. Meskipun sebenarnya dapat dimanfaatkan dengan adanya komunitas untuk kegiatan bisnis, namun mereka nengenepikan persoalan materil. Selain itu, hal tersebut juga membangun komunikasi dan keakraban antar sesama kelompok.

Adanya kegiatan yang diselenggarakan oleh komunitas hijabers ini juga berbentuk dalam kegiatan yang diadakan 1 (satu) kali dalam setahun sesuai dengan kesepakatan antara pengurus dari forum tersebut. Kegiatan tersebut dirangkum dalam sebuah acara yang bertemakan Hijab Day.

"Bentuk festival yang dilakukan hijabers disebut sebagai Hijab Day atau harinya hijabers." (Agma, 25 Mei 2017).

Festival dalam komunitas hijabers yang kerap dipanggil dengan sebutan Hijab Day memiliki tujuan dimana kembali kepada niat awal, bahwa hijabers ini memiliki tujuan untuk menjalankan syair Islam, berbagi ilmu dan pengalaman, serta hal-hal yang bersifat positif. Menurut seorang narasumber:

"Festifal lebih ke acara hijab day atau harinya hijabers, kini telah berganti nama hijabers community day" (Ika Adamsari, 27 Mei 2017).

"Tujuannya diadakan kegiatan untuk kegiatan syiar, berbagi pengalaman, sharing ilmu yang penting fositif" (Agustarifa, 27 Mei 2017).

Seringkali komunitas tersebut menamai acara tertentu dengan sebutan spesial. Salah satu nama yang seringkali digunakan dengan hari jilbabers (Hijab Day). Hari Hijab Day yang dilakukun hanya 1 hari saja sebagai acara yang sangat spesial bagi komunitas tersebut. Hal ini dikarenakan acara tersebut merupakan suatu acara yang dianggap penting dan memiliki makna dan tujuan religi. Hal ini merupakan penting untuk dirancang sedemikian rupa agar menarik bagi wanita lainnya. Acara Hijab Day ini biasanya dilaksanakan di sebuah hotel di Kota Padang, dan diikuti dengan beberapa rangkaian acara yang menarik. Acara ini terdapat beberapa rangkaian acara seperti penjelasan narasumber:

"Festival fashion show, talk show, bazar dan pengajian dilakukan di sebuah hotel, di ball room" (Ika Adamsari, 27 Mei 2017).

Data di atas menjelaskan bahwa acara yang dirangkum oleh komunitas hijabers merupakan kegiatan yang dirancang dengan serius. Keseriusan ini juga tentu memiliki biaya yang sangat banyak. Namun pengurus komunitas ini bukanlah suatu hambatan untuk menjalankan kegiatan dan kepengurusan komunitas tersebut. Selain merupakan ladang amal, juga merupakan ajang silaturahmi yang besar bagi para wanita. Hal ini dianggap positif dalam mendorong para perempuan lain untuk berhijab dan berkehidupansosial. 
Terkait dalam acara hijab day, beberapa kegiatan dilakukan oleh komunitas hijabers, antara lain: Fashion show: merupakan acara yang dilakukan dengan peragaan busana dari beberapa koleksi butik Ria Miranda. Fashion show ini bukanlah sebuah lomba melainkan satu bentuk peragaan koleksi yang bertujuan untuk memperlihatkan kepada publik apa saja koleksi terbaru dari butik tersebut. Menariknya dari fashion show tersebut, dimana masyarakat yang tidak tahu tentang koleksi terbaru dari butik Ria Miranda akhinya bisa tahu apa saja koleksinya. Sehingga, kalau ada yang tertarik dengan koleksi Ria Miranda tersebut nanti bisa juga menjalin kerja sama antar pemilik butik.

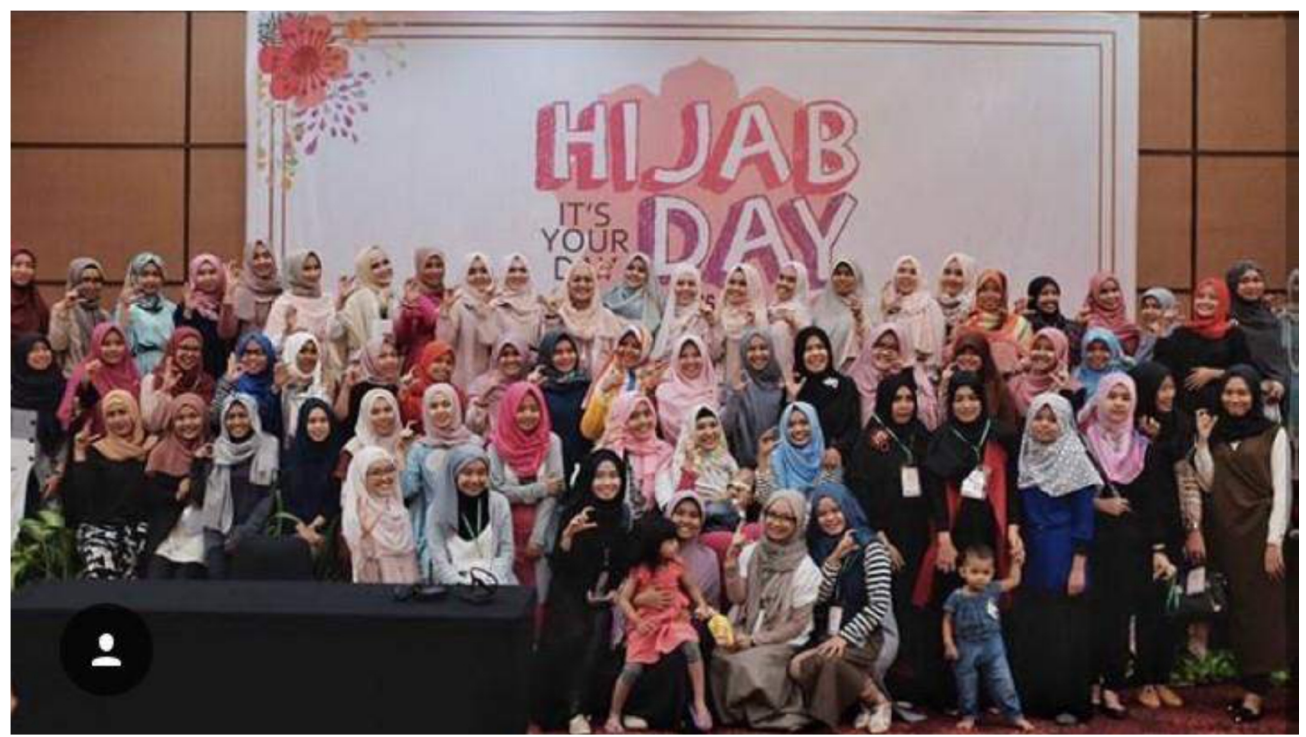

Gambar 2. Pelaksanaan kegiatan Hijab Day

Alasan memilih fashion show sebagai salah satu kegiatan pada Hijab Day bertujuan untuk menunjukan kepada orang-orang bahwa berhijab itu tetap bisa modis, cantik, lebih menarik masa, dan yang paling penting tidak keluar dari syariat Islam. Fashion show ini di peragakan oleh seorang model, model tersebut disewa untuk memperagakan koleksi dari butik tersebut. Dalam hal ini, acara dari fashion show tidak membataskan usia, siapa saja diperbolehkan hadir untuk mengikuti serangkaian acara, dan juga tidak memandang agama. Acara ini juga merupakan bentuk syiar kepada perempuan yang belum memakai berhijab.

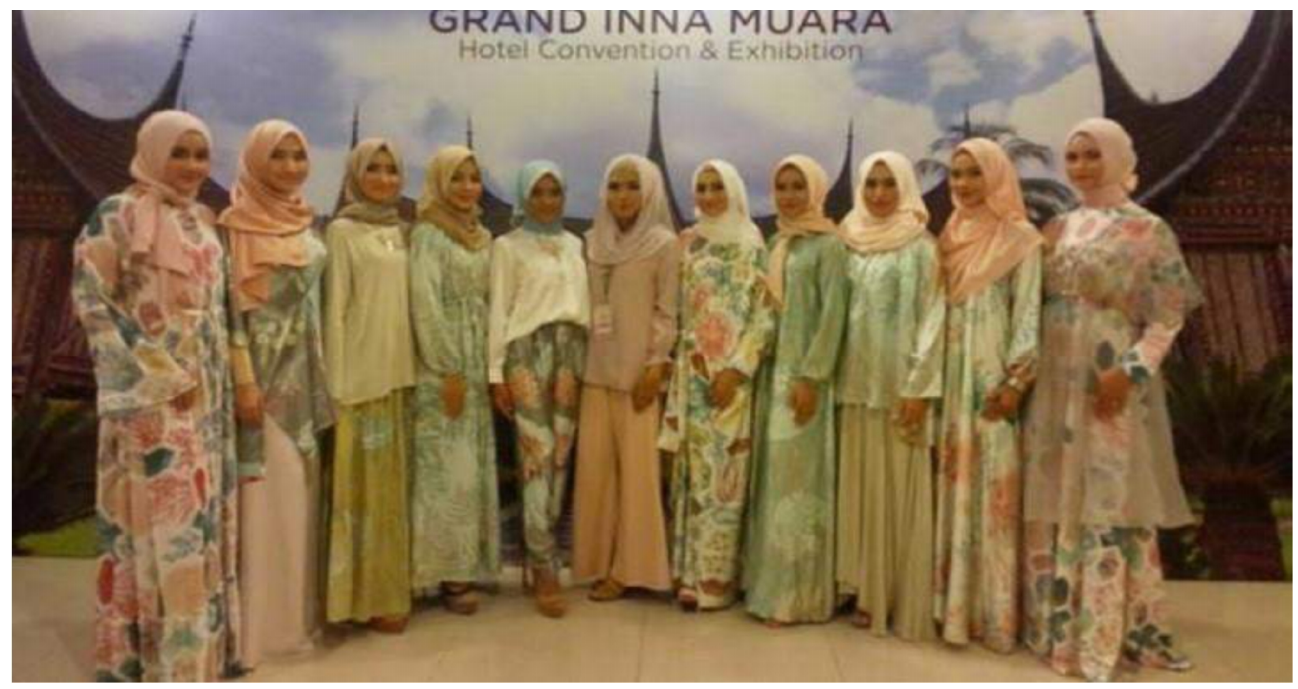

Gambar 3. Model Memperagakan Koleksi Salah Satu Butik 
"Peserta yang datang bukan hanya mahasiswa saja atau ibu rumah tangga saja, kita dari semua kalangan yang penting perempuan, jadi yang membuat menarik dari fashion show kita biasanya pakai koleksi dari desainer seperti Ria Miranda. Kita tidak membataskan usia, kita tidak membataskan agama, non muslim juga boleh ikut acara kita, karna tujuan kitakan juga untuk mensyiarkan agama kepada siapa saja, siapa tau mereka setelah mengikuti acara kita mereka terketuk untuk pindah agama, yang penting harus perempuan. Cuma cukup harus perempuan dan anak SMA boleh menghadiri acara ini.." (Wawancara Agustarifa, 27 Mei 2017).

"Menghidupkan acara fashion show ini karna lebih menarik masa, yang kedua ingin bahwa memakai baju yang tertutup itu tetap bisa bergaya, yang penting tidak keluar dari syariat Islam." (wawancara, Ika Adamsari, 27 Mei 2017).

Seperti yang telah dijelaskan di atas, hal tersebut menggambarkan bahwa hijabers memiliki cara tersendiri dalam mensyiarkan misi dari komunitas, dalam mengolah kegiatan hingga menjadi kegiatan yang mampu dikemas secara menarik untuk dijadikan sebuah bentuk pertunjukan fashion busana muslim. Hal ini bertujuan agar publik mengubah pandangan terhadap pemakaian hijab yang monoton. Selain itu, melalui acara yang diselenggarakan merubah cara pandang wanita selama ini bahwa berjilbab bukan lagi suatu yang dianggap kuno karena berjilbab sudah berkembang penggunaannya.

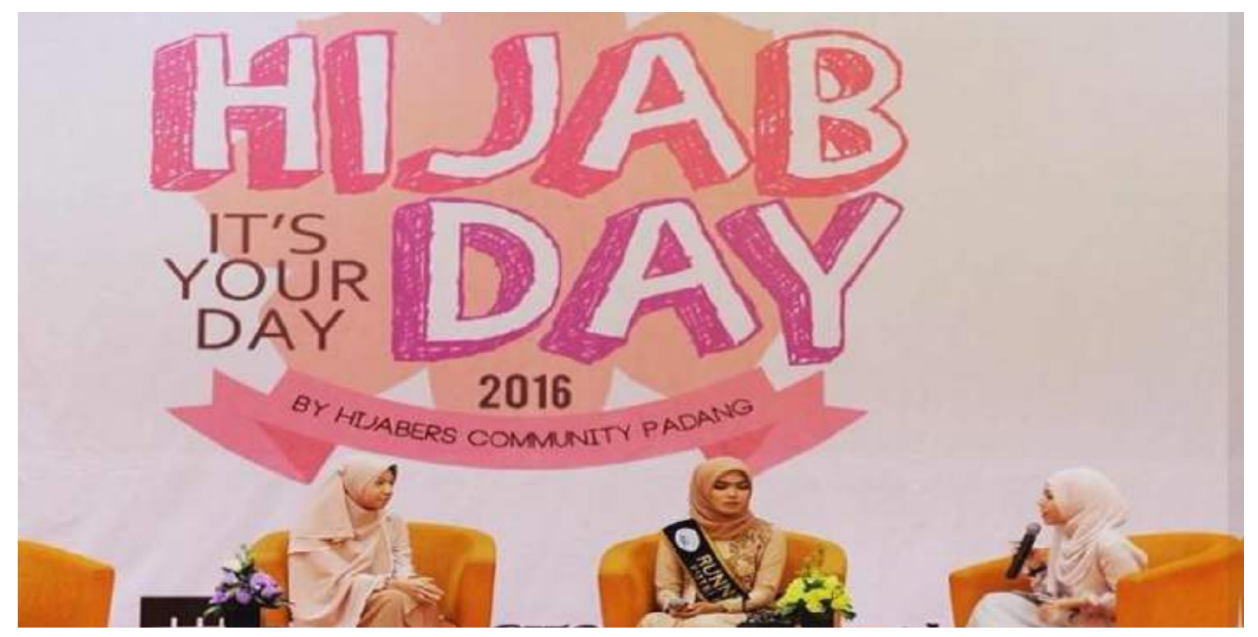

Gambar 4. Talkshow Berbagi Pengalaman

Talk Show merupakan kegiatan mewawancarai seseorang dengan menampilkan perbincangan tersebut di tempat tertentu. Acara Talk Show juga mengundang tamu-tamu penting untuk memeriahkan acara. Pembawa acara Talk Show biasanya berasal dari anggota maupun pengurus hijabers. Pengambilan tema tidak jauh-jauh dari topik yang sedang tren untuk diperbincangkan. Tema Talk Show ini juga tidak jauh-jauh dari fashion hijab, pengalaman hidup, motivasi dan hal- hal yang bermanfaat untuk peserta. Tamu yang diundang biasanya diambil dari selebgram yang muslimah. Sejauh perjalanan berdirinya komunitas hijabers hanya mampu mengundang selebram saja dikarenakan terkendala dana. Jika mengundang seorang artis, maka akan membutuhkan biaya yang sangat mahal. Selebgram yang menjadi tamu dari Talk Show ini diambil juga dari selebgram Kota Padang. Jika ada yang mau mensponsori acara Talk Show, komunitas ingin mengundang tamu dari pusat. Target acara Hijab Day untuk ke depannya ingin mengundang tamu dari pusat. Berikut penjelasan secara langsung oleh narasumber:

"Talk show itu kita undang orang-orang yang lebih terkenal dalam segi fashion, seperti bitang tamu selebgram, selebgram yang berkerudung terus sejauh ini kita undangnya selebram bukan artis, untuk mengundang artis untuk luar Kota lumayan dibutuhkan dana besar. Kalo ada yang nyemonsoriin kita ingin tamunya dari pusat. Abis itu sih targetnya acara hc sekarang ini dari pusat"(wawancara, Ika Adamsari, 27 Mei 2017). 
"Talkshow hanya ada di hijab day, pemilihan tema nya kita mengembalikan lagi ke masyarakat apa yang lagi happening acara yang mau diadakan itu apa, seperti onlineshop kan lagi happening jadi kita Talk Show tentang inter prener lalu cari nara sumbernya yang semampu nya gak memaksakan hijabers yang jelas semampunya acaranya jalanpesertanya puas gitu" (Wawancara Agustarifa, 27 Mei 2017).

Data tersebut dapat dipahami bahwa komunitas ini memang meengadakan Talk Show untuk melakukan wawancara demi memotivasi para pendengar, tamu yang diundang diambil dari selebram Kota Padang, dengan memakai host dari hijabers. Pemilihan tema lebih fokus kepada topik yang sedang banyak diperbincangkan dalam kalangan publik, hingga acara yang dilakukan dapat bermanfaat bagi pendengar.

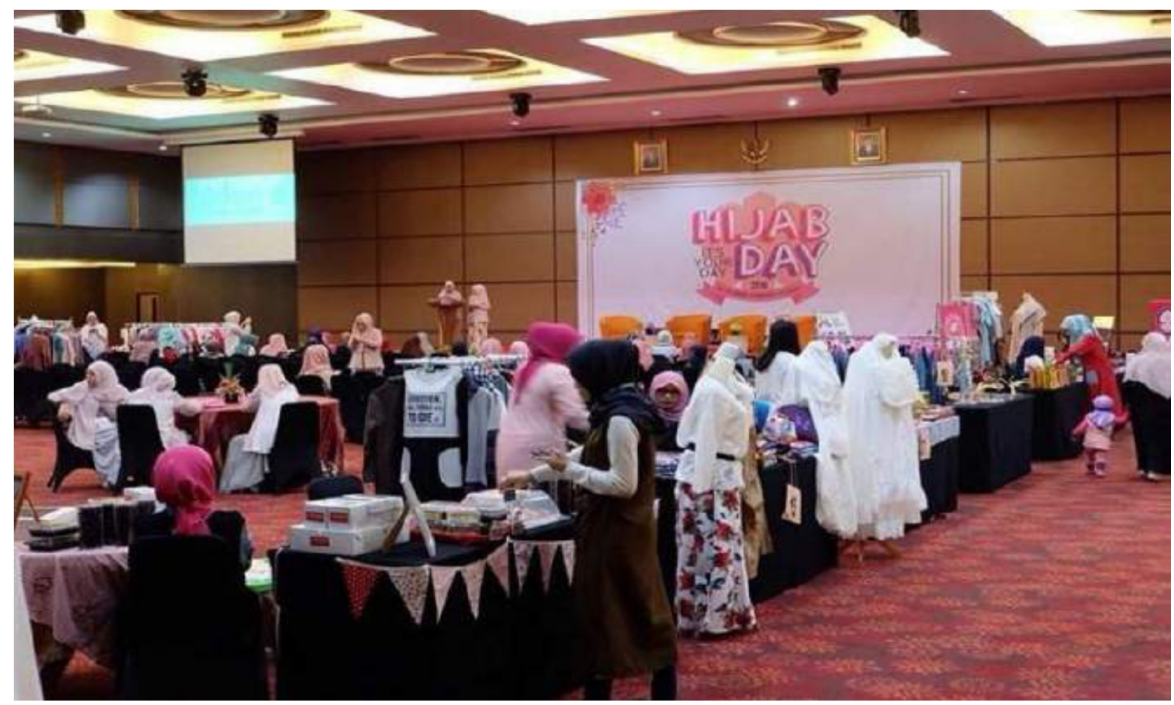

Gambar 5. Suasana Bazar

Bazar merupakam kegiatan komunitas hijabers dengan menjual booth (tempat dagang) kepada orang-orang yang ingin menjual barang dagangannya. Biasanya, setiap pedagang yang menjual barang dagangannya memberikan sebuah diskon tergantung kepada pihak penjual. Dalam berjual beli, komunitas hijabers tidak mengharuskan dalam urusan jual beli, komunitas hanya memberi tempat kepada para penjual yang ingin berpartisipasi terhadap kegiatan hijabers (Agustarifa : 2017). Dalam kata lain, hijabers tidak ikut campur dalam urusan penjualan. Kegiatan bazar menjual berbagai bentuk pakaian muslim. Seperti yang penulis kutip dari wawncara dengan narasumber:

"Berkumpul dalam konteks gaya hidup merupakan hal yang biasa, jadi hijabers ingin mengubah arti berkumpul itu menjadi suatu hal yang menarik, seperti mengadakan bazar dan event-event yang akan dilakukan oleh hijabers." (wawancara, Ika Adamsari, 27 Mei 2017).

Dari penjelaskan diatas dapat dipahami bahwa hijabers ingin mengemas suatu perkumpulan menjadi menarik. Melalui event bazar, gaya hidup modern saat ini menjadi suatu hal yang menarik.

Pengajian: Kegiatan pengajian dilakukan pada satu bulan sekali. Pengajian ini di masukan ke dalam acara Hijab Day dikarenakan Hijab Day merupakan harinya hijabers. Sehingga pada acara Hijab Day, semua kegiatan yang dilakukan oleh komunitas ini akan dijadikan satu rangkaian acara dalam satu hari.

"Festival dalam hijab day atau harinya hijabers, dengan mengadakan suatu acara seperti fashion show, talk show, bazar, sama pengajian" (wawancara, Ika Adamsari, 27 Mei 2017). 


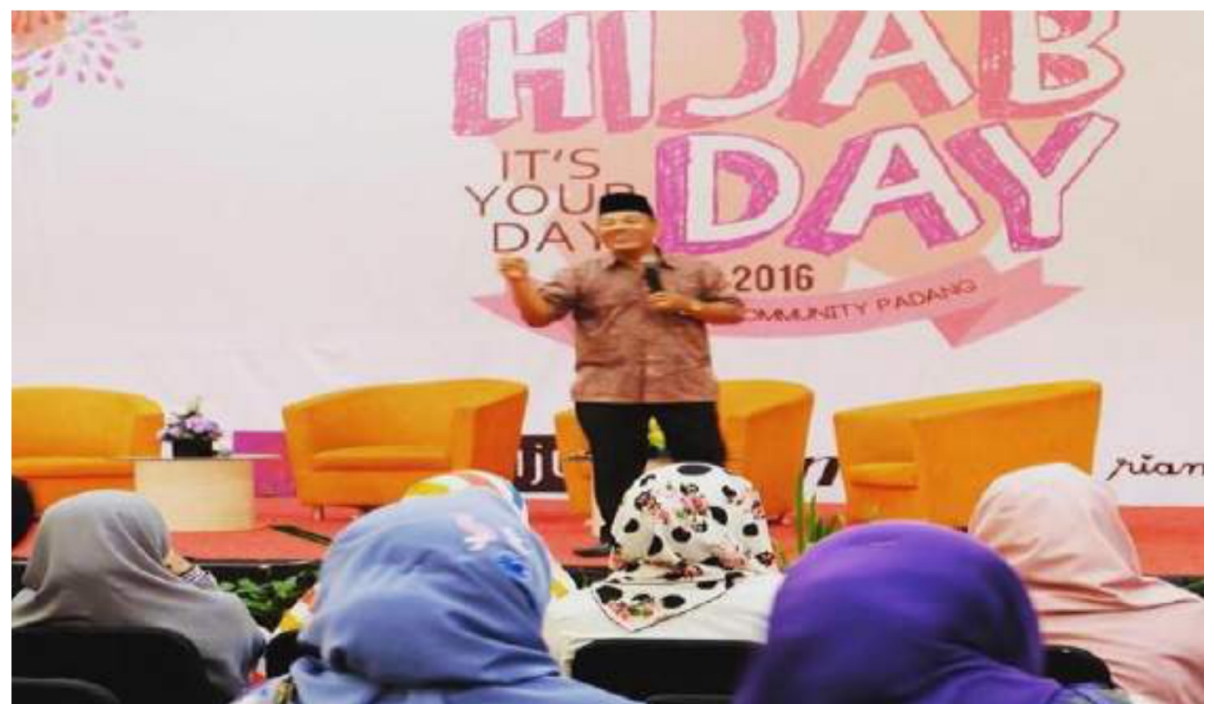

Gambar 6. Ceramah Agam Dalam Acara Pengajian

Pengajian dengan ustaz: Kegiatan keagamaan dan dakwah keagamaan merupakan kegiatan rutinitas yang dilakukan oleh komunitas hijabers setiap bulan. Hal ini dilakukan setiap bulan karena persiapan pengajian terbilang mudah. Salah satu anggota komunitas hijabers mengutarakan bahwa dalam melakukan pengajian, yang perlu di lakukan hanya memikirkan tentang tempat, biaya dan siapa yang akan menjadi pemateri pada saat pengajian.

"Kalau pengajian, persiapannya lebih murah, cari tempat di masjid kemudian cari ustaz yang bersedia untuk memberi pengajian" (wawancara, Ika Adamsari, $27 \mathrm{Mei}$ 2017)

\subsection{Komunitas dan Praktik Keagamaan}

Pemilihan tema pengajian lebih beragam pada topic, tidak mesti harus berpatokan tentang fashion maupun agama. Komunitas hijabers lebih memilih tema yang sedang diperbincangkan di lingkungan sekitar seperti tentang pengajian yang telah dilakukan dengan bertemakan menikah muda. Melalui tema kaum muda, ide ini bertujuan untuk menarik simpati kaum muda untuk berpartisipasi ke dalam acara sehingga mendapatkan ilmu dan pengalaman yang bersifat positif.

"Tema kita lebih beragam. Tidak harus fashion, tetapi lebih kepada apa yang sedang tren, kedua mungkin kita tergantung pasarnya anak muda seperti tema menuju halal. Untuk anak-anak muda biar termotifasi, agar kita tahu antar sesama lawan jenis itu seperti apa baiknya" (wawancara, Kartika2017).

Dapat dipahami dari data di atas, bahwa dalam penyelenggaraan kegiatan yang di lakukan oleh komunitas hijabers tidak diharuskan berbicara tentang fashion, akan tetapi lebih kepada tren atau isu yang sedang banyak diperbincangkan. Pemilihan materi pengajian dilakukan dengan cara meminta kesepakatan bersama. Komunitas mendiskusikan pemateri acara pengajian, seperti pada minggu pertama bersama ustaz Ramadhan, minggu kedua dengan ustaz Taufiq, dan minggu ketiga bersama ustazah yusnina sebagai pemateri dalam acara pengajian. Dikarenakan kontak pemateri yang ada pada komunitas ini sedikit, pemilihan pemateri dilakukan secara berurutan. Materi acara pengajian tidak memakai penceramah yang suka menjelekan jamaah yang lain. Kegiatan pengajian ini dilakukan untuk mendapat ilmu agama bukan untuk menggosipkan jemaah yang lain. 
"Dalam pemilihan pemateri diundang secara berurutan, dan juga ada pemilihan ustaz dengan pemungutan suara dengan memberikan obsi beberapa ustaz dan nanti dipilih secara bersama bagi anggota maupun komunitas hijabers" (Wawancara Agma 2017).

"Kategori pemilihan penceramahnya pematerinya tidak mesti perempuan. Kita juga sering memakai ustaz laki- laki, yang penting itu tidak suka menjelekan jamaah yang lain. Karena tujuan kita gak mencari keburukan seseorang, tapi mencari dan menggali ilmu agama gitu, memperdalam lagi." (wawancara Agustarifa 2017).

Dari penjelasan diatas dapat dipahami bahwa adanya kegiatan pengajian bertujuan untuk menambah ilmu agama, pengalaman serta memperdalam silaturahmi antar sesama. Hal ini diatur sedemikian rupa, seperti dalam memilih pemateri yang menyampaikan ilmu agama, dan tema yang digunakan juga akan di kemas sedemikian rupa agar menari bagi para pendengar. Sehingga akan memunculkan stimulus bagi kalangan anak muda, khususnya adalah perempuan untuk ikut bergabung dalam komunitas pengajian yang diadakan. Tujuan dari terbentuknya acara yaitu untuk mengait peminat yang merupakan arah utama bagi komunitas hijabers dalam menyiarkan pemahaman keagamaan. Hal ini sangat berkaitan erat dengan followers komunitas. Dengan banyaknya like dari media sosial, juga akan mempengaruhi kehidupan pribadi bagi perempuan yang lain. Jadi, hal tersebut akan menumbuhkan motivasi bagi perempuan lain untuk mengikuti pengajian yang di adakan. Seperti yang telah dikatakan oleh narasumber seperti berikut:

"Dilihat respon dipostingan atau yang nyata, lebih banyak yang dunia nyatanya, mereka hadir lansung, langsung datang lihat pengajian (Wawancara Agma, 2017).

Pernyataan di atas dapat dipahami bahwa antusias dari publik terhadap pengajian sangatlah baik, publik lebih banyak terlibat langsung dengan acara dibandingkan yang hanya melihat postingan dari group hijabers tersebut.

Meskipun rutinitas yang diadakan oleh komunitas ini mengatasnamakan kegiatan agama, bukan tidak mungkin terjadi perbedaan pendapat. Seringkali dalam kegiatan yang diadakan juga pernah terjadi perbedaan pandangan pada kegiatan yang akan dilaksanakan. Persoalan yang paling riskan adalah dalam menetapkan waktu. Pertama, waktu menjadi persoalan bagi anggota yang terhimpun dalam komunitas hijabers dalam melaksanakan acara, maupun dalam kegiatan pengajian keagamaan. Namun perbedaan itu tidak menyurutkan semangat yang dimiliki dalam mengelola komunitas yang dibentuk. Kedua, adalah persoalan keuangan yang kadang tidak memadai untuk melakukan kegiatan. Hal tersebut dikarenakan tidak memiliki donator yang jelas dalam pelaksana komunitas yang dijalankan, seringkali para anggota melakuan patungan dalam pendanaan kegiatan. Menurut salah seorang narasumber:

"Ketika setelah acara pengajian selesai, kita juga meminta sumbangn ala kadarnya kepada para pendengar ceramah, setelah itu jika sudah terkumpul, ada salah satu anggota yang nanti memberikan semua uang yang terkumpul kepada dompet duafa"( Ika Adamsari : 2017).

\subsection{Sharing Pengetahuan Komunitas Hijabers di Kota Padang}

Seperti yang sudah di singgung pada bagian sebelumnya bahwa komunitas hijabers juga memiliki rutinitas pertemuan 1 kali dalam 3 bulan. Kegiatan tersebut dinamakan sharing ilmu pengetahuan. Dalam kegiatan sharing ilmu pengetahuan, para anggota berbagi tutorial dalam penggunaan hijab yang digunakan.

Tutorial hijab dan Demo Makeup; yaitu acara berbagi ilmu dan pengalaman tentang pemakaian hijab dan cara pemakaian makeup yang sederhana namun tetap menarik. Acara dilakukan disela waktu seperti setelah mengadakan pengajian bulan. Meskipun dilakukan pada saat setelah pengajian bulanan untuk perempuan yang ingin mengikuti rangkaian, acara ini harus membayar insert sebesar Rp 35.000 untuk umum dan Rp 30.000 untuk anggota hijabers. Acara ini dilakukan di salah satu hotel di Kota Padang. Adapun penjelasan dari narasumber: 
"Hijab day out itu merupakan acara dengan event yang dilakukan hijabers disertai dengan acara pengajian, acara hijab day out ini dilakukan di luar ruangan. Terakhir dilakukan di hotel inamuara" (Wawancara Agma, 2017).

Dari hasil wawancara tersebut dapat dipahami bahwa tutorial merupakan kegiatan yang dilakukan dengan disertai even, namun tetap saja bernuansa kegamaan. Arti lain bahwa kegiatan yang diselenggarakan adalah bagian dari rutinitas keagamaan yang sudah di rancang. Hanya saja sisi lainnya adalah di sesi jeda acara akan dilakukan tata rias dalam tutorial berjilbab.

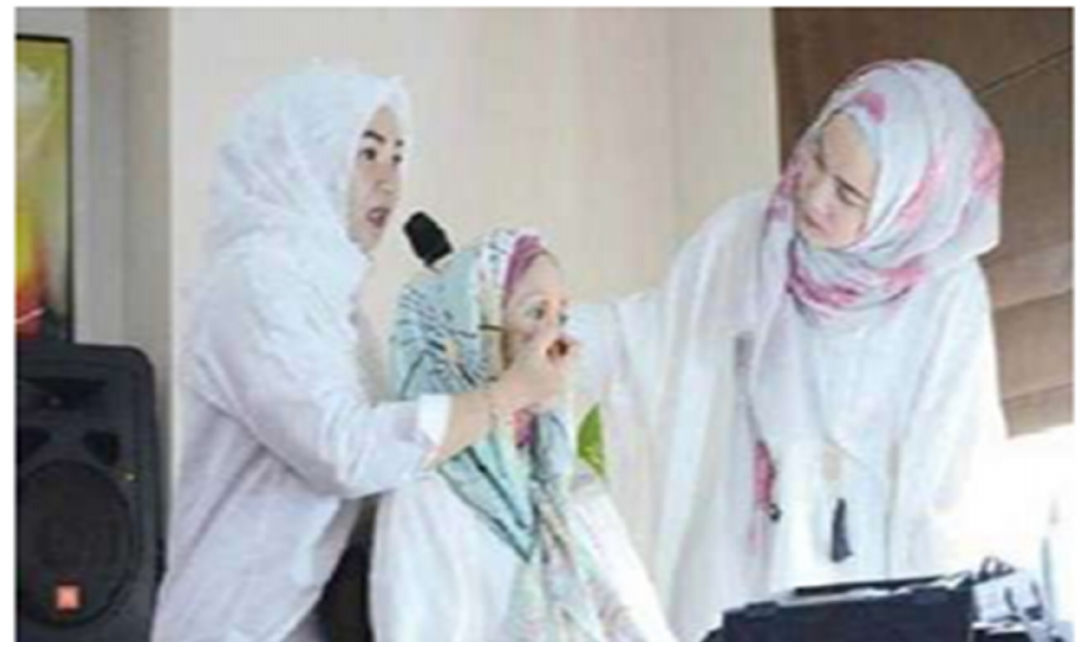

Gambar 7. Proses Tutorial Hijabers

Selain itu, hijab out dalam acara yang dilakukan dikemas dalam bentuk seminar, dengan pemilihan tema yang didiskusikan secara matang seperti blogger. Narasumber merupakan pemateri yang paham akan blogger. Kegiatan ini juga digunakan sebagai tempat berbagi pengalaman tentang bagaimana menggunakan blogger untuk berjualan maupun sebagai tempat berbagi ilmu saja. Seperti yang dijelaskan narsumber:

"Hijab day out itu seperti seminar tentang apa yang lagi trend contohnya blogger, kita juga pernah membuat blogger, dan pada acara ini juga ada narasumber"(Kartika,2017).

Dapat dipahami bahwa segala sesuatu acara yang dirancang oleh komunitas tersebut berupaya agar tidak mengalami acara keagamaan yang monoton. Maka acara yang diadakan perlu diadakan semenarik mungkin.

\section{Community Hijaber; Antara Agama dan Gaya Hidup}

Komunitas hijaber yang dibentuk seakan merupakan tempat baru untuk berdiskusi berbagai hal dalam gaya dan penampilan. Uniknya, rutinitas pertemuan yang dilakukan oleh komunitas tersebut tidak di rumah, tetapi di masjid. Bentuk kegiatan yang dilakukan seperti acara tausiah keagamaan serta rapat internal pengurus komunitas. Ada beberapa hal dalam kegiatan yang dilakukan oleh komunitas dalam pertemuan tersebut. Pertama, kegiatan rapat dilakukan setiap bulan dan bersifat wajib dihadiri oleh komite dari komunitas hijabers. Komunitas memiliki agenda untuk membahas acara apa yang akan dilaksanakan serta kegiatan untuk mengevaluasi dari apa yang telah dilakukan. Kedua; kegiatan pengajian adalah bentuk kegiatan rutin dilakukan oleh komunitas hijabers. Kegiatan ini diselenggarakan dalam masjid di Kota Padang, serta acara ini bukan untuk anggota maupun komite komunitas saja melainkan dibuka secara umum. Kegiatan dilaksanakan dalam bentuk tausiyah oleh seorang ustaz maupun ustadzah dengan pembukaan, pembacaan al-Quran yang dibacakan oleh salah satu anggota dari komunitas. 
Selain itu penentuan tema yang dibicarakan oleh anggota komunitas dengan cara berdiskusi dan dialog oleh pengurus dan anggota. Tema yang di usulkan harus merujuk pada pakaian seorang wanita saat ini. Hal tersebut dianggap bagian dari terbentuknya komunitas tersebut sebagai promotor penggerak dari Hijabers community.

Demikian halnya dengan pemateri seperti ustaz dan ustazah yang di minta oleh komunitas hijaber untuk memberi tausiah. Topik yang dibicarakan sudah ditentukan dan diarahkan oleh pengurus komunitas, sehingga tidak diperbolehkan untuk menjelekan jamaah yang hadir dalam acara tersebut. Hal ini dilakukan mengingat yang hadir adalah orang-orang baru yang akan diberi arahan agar menimbulkan kesadaran untuk menggunakan hijab. Bagi para anggota kumunitas yang hadir juga sudah diberi aturan bahwasannya tidak diperbolehkan untuk berpakaian transparan, legging. maupun jean. Tetapi untuk para anggota ataupun untuk umum maka hanya mewajibkan pemakaian busana yang sopan serta sesuai dengan kondisi. Hal tersebut dilakukan agar komunitas tersebut memberikan contoh dari kajian yang sudah di sampaikan oleh pemateri dari ustaz dan ustadzah. Ketiga; Hijab Day adalah acara yang dilakukan oleh komunitas satu kali dalam 3 bulan. Acara tersebut bertujuan untuk berbagi pengalaman tentang tutorial seperti hijab class. Kegiatan tersebut dilakukan semua komite untuk berbagi pengalaman kepada para anggota komunitas agar tetap berpakaian syar'i sederhana, namun tetap menarik. Kegiatan ini berbentuk tutorial pemakaian hijab dengan bermacam-macam gaya dan kreasi, demo makeup dan biasanya dipraktikkan oleh salah satu komite dari hijabers. Selain itu , komunitas juga aktif memberikan makeup terhadap para wisudawati di kampus. Hal itu dilakukan sebagai salah satu cara untuk mempromosikan kepada orang lain bentuk gaya hijab yang lebih kreatif dalam penggunaannya. Mereka juga membagikan diberbagai media sosial dari pelanggan yang menggunakan jasa.

Dalam acara hijab day, secara garis besarnya bertemakan tentang pengalaman, menambah ilmu untuk hal-hal baru. Selain itu, pemilihan tema, di serahkan langsung pada permintaan anggota maupun publik. Keempat; hijab day adalah acara yang dilakukan oleh komunitas hijabers 1 kali dalam 1 tahun. Acara ini merupakan gabungan dari beberapa acara yang telah dilakukan komunitas maupun acara yang baru diselenggarakan, seperti pengajian, talkshow, fashion show, dan bazar. Acara fashion show yang diselenggarakan merupakan sebuah acara yang memperagakan busana muslim dari salah satu butik di Kota Padang, seperti butik Ria Miranda Padang. Namun fashion show tersebut bukan suatu ajang perlombaan, melainkan hanya memperagakan busana dari desainer terkenal dalam rangka memperkenalkan model dan trend desainer tersebut. Selain acara fashion show, komunitas tersebut juga mengadakan acara talkshow.

Talkshow merupakan sebuah acara dalam bentuk wawancara dengan salah satu tamu yang diundang. Tamu yang diundang dalam acara tersebut merupakan selebgram muslimah Kota Padang, yang bertujuan untuk memperbincangkan berbagai hal yang berkaitan dengan pakaian muslimah, kehidupan seorang muslimah dan hal lainnya. Selain itu, tema talkshow yang dipilih juga beragam seperti talkshow yang diselenggarakan tahun 2017 dengan tema tentang menikah muda. Tema ini diusulkan berdasarkan kesepakatan bahwa tahun 2017 tersebut banyak dari para jilbaber yang memutuskan untuk menikah muda. Selain acara talkshow, komunitas tersebut juga mengadakan pengajian seperti hijab day. Namun, acara yang dilakukan pada acara hijab day lebih lama dibandingkan dengan pengajian lain. Pengajian hijab day membuka diskusi dan tanya jawab dengan durasi yang cukup lama bertujuan agar semua muslimah yang ingin bertanya mendapatkan giliran. Selain itu, juga ada acara seperti bazar yang diselenggarakan untuk berjualan bagi komunitas ketika acara.

Berbeda dengan acara sebelumnya, bazar merupakan kegiatan yang dilakukan untuk memberikan suatu kesan yang beda terhadap pengunjung. Acara hijab day merupakan kegiatan yang dilakukan dengan memberikan ruang kepada para penjual untuk mempromosikan dagangan, dan biasanya para penjual memberikan diskon kepada para konsumen. Hal ini tentu saja akan menumbuhkan minat bagi para pedagang untuk 
berpartisipasi dalam acara tersebut. Sehingga secara tidak langsung, kegiatan ini tentu saja sudah termasuk dari iklan bagi hijab itu sendiri.

Berdasarkan pada hasil analisa, kemunculan komunitas Hijabers di Kota-Kota besar yang salah satunya adalah Kota Padang merupakan bentuk pengaruh keagamaan yang salah. Hal tersebut dijelaskan oleh George Herbert Mead yang menjelaskan hal demikian menjadi bagian dari gerakan simbolik (Ritzer \& Goodman, 2010). Dapat dipahami bahwa jilbab merupakan upaya dalam misi tertentu untuk mempengaruhi orang lain melalui gaya hidup (fashion). Tampilan menarik dan unik, tentu akan dapat meningkatkan kepercayaan seseorang untuk kembali menggunakan jilbab. Meskipun sebenarnya, masyarakat tidak memahami apa yang melandasi serta pondasi keagamaan dalam mengikuti dan mempengaruhi jiwa dan kehendak seseorang untuk menggunakannya. Selain itu, komunitas jilbabers juga merupakan bagian dari identitas yang mesti di lestarikan serta di kelola agar selalu menjadi daya tarik bagi orang lain.

Di sisi lain, dapat juga dipahami bahwa terbentuknya komunitas hijabers tersebut merupakan upaya seseorang dalam meraup keuntungan dalam bidang bisnis. Dengan meningkatnya penggunaan jilbab, tentu saja memiliki keuntungan tersendiri bagi pengusaha hijab dalam menyesuaikan pasar (peminat). Menurut Kotler dan Amstrong gaya hidup dapat dipahami sebagai bagian yang terpenting dalam kehidupan sosial (Rianto, 2013). Sehingga sulit untuk dipisahkan dalam keuntungan finansial. Berkembangnya gaya hidup, tentu juga akan meningkatnya pendapatan bagi kehidupan orang lain, salah satunya adalah bagi pengusaha jilbab.

Ada beberapa pola yang dapat dipahami dalam kajian ini dari teori yang dikemukakan: pertama adalah memiliki misi tertentu, kedua adalah identitas keagamaan, dan ketiga adalah bisnis. Sehingga kaitan tersebut merupakan bagian terpenting yang sulit dipisahkan antara satu dengan yang lainnya. Di antara satu-kesatuan tersebut berkaitan erat dan juga saling menguntungkan antara satu dengan yang lainnya.

\section{Kesimpulan}

Lahirnya komunitas hijabers atau yang di kenal dengan Hijabers Community beranjak dari kesuksesan dari komunitas hijabers dari pusat sebagai wadah berbagi pengalaman. Dengan demikian, mendorong motivasi seseorang baik secara individu maupun secara kelompok dalam membentuk komunitas untuk mengajak para wanita di Kota Padang dalam berhijab secara modern. Misi utama yang ingin di sampaikan, pertama, bahwa berhijab tidak lagi di anggap sebagai suatu yang kuno dan monoton. Sehingga, dengan adanya wadah dalam berbagi berbagai bentuk gaya dan bentuk jilbab yang menarik, akan merubah persepsi orang lain dalam menggunakan jilbab. Kedua, terbentuknya komunitas hijabers merupakan cara baru dalam mengajak perempuan muslimah di kota padang untuk mengikuti kegiatan-kegiatan keagamaan, seperti: kegiatan pengajian rutin setiap bulan, bertempat di mesjid, dengan berbagai topik yang berbeda-beda setiap bulannya, serta pemateri yang berbeda setiap bulan. Selanjutnya, kegiatan sharing, serta menambah ilmu yang diselenggarakan 3 bulan 1 kali seperti; acara seminar tentang bagaimana menggunakan website toko online agar berjalan dengan lanjar. Terakhir, kegiatan yang dilaksanakan hanya 1 kali dalam 1 tahun, kegiatan ini dilaksanakan dalam 1 hari dengan menggabungkan semua kegiatan hijbers, seperti; fashion show, talkshow, pengajian dan bazar. Ketiga, Dari hasil temuan terkait dengan praktek keagamaan dari komunitas hijabers Kota Padang, bahwa komunitas ini merupakan sekumpulan perempuan berhijab yang menyalurkan kreasi serta ragam gaya berhijab di kalangan publik. Komunitas memiliki target dalam membentuk akhlak yang lebih baik setiap hari melalui kegiatan pengajian. Acara dikemas semenarik mungkin sehingga mampu menyampaikan pesan kepada publik. Tidak hanya pengajian saja, tetapi komunitas ini menyampaikan pesan tentang penggunaan hijab dan busana yang menarik dan tidak ketinggalan zaman, sehingga komunitas ini mengekspresikan gaya hidup beragama melalui pemakaian hijab yang fashionable. 


\section{Daftar Pustaka}

Andriani, M., \& Ni'matuzahroh. (2013). Konsep Diri dan Konformitas Pada Komunitas Hijabers. Jurnal Ilmiah Psikologi Terapan, 1(1), 110-126.

Anggraini, W. (2016). Fenomena Komunitas Hijabers di Kota Padang ( Studi Kasus: Hijabers Community Padang (HCP) ). STKIP PGRI Sumatera Barat.

Fachri, N. F. (2013). Pemaknaan Identitas Diri Anggota Hijabers Community di Yogyakarta. UIN Sunan Kalijaga.

Huda, Y. M. (2014). Gaya Hidup Hijabers Pekanbaru (Studi Deskriptif Kualitatif). UIN Sultan Syarif Kasim.

Kotler, P., \& Amstrong, G. (2008). Prinsip-Prinsip Pemasaran. Jakarta: Erlangga.

Noer, H. M. A. (2016). Pengaruh Pengetahuan Berhijab dan Perilaku Keagamaan Terhadap Motivasi Berjilbab Mahasiswi Pendidikan Agama Islam. Jurnal Pendidikan Agama Islam Al-Thariqah, 1(2), 172-192. https://doi.org/10.25299/althariqah.2016.vol1(2).630

Notoatmodjo, S. (2003). Pendidikan dan Perilaku Kesehatan. Jakarta: Kencana.

Ramadhini, E. (2017). Jilbab sebagai Representasi Simbolik Mahasiswi Muslim di Universitas Indonesia. Masyarakat, Jurnal Sosiologi, 22(1), 81-103.

Rianto, R. (2013). Hubungan antara Konformitas Kelompok Teman Sebaya dengan Gaya Hidup Hedonis pada Mahasiswa Kab. Dhamasraya Di Yogyakarta. EMPATHY Jurnal Fakultas Psikologi, 2(1).

Ritzer, G., \& Goodman, D. J. (2010). Teori Sosiologi Modren. Jakarta: Kencana.

Sari, C. P. (2016). Pengaruh Hijabers Community dan Gaya Hidup Terhadap Minat Beli Jilbab Merek Elzatta. Universitas Narotama Surabaya.

Sugiyono. (2005). Metode Penelitian Administrasi. Bandung: Alfabeta.

Sumarwan, U. (2004). Perilaku Konsumen; Teori dan Penerapannya Dalam Pemasaran. Bogor: Ghalia Indonesia.

Sutopo. (2006). Metodologi Penelitian Kulitatif. Surakarta: Universitas Sebelas Maret.

Tahir, M., \& Triantini, Z. E. (2014). Menakar Kontekstualisasi Konsep Jilbab Dalam Islam. QAWWAM, 8(1), 1-12.

Tajfel, H. (1974). Sosial Identity and Intergroup Behaviour. Social Science Information, 13(2), 65-93. https://doi.org/10.1177/053901847401300204

Ulfa, R., Wulandari, D., \& Subagio, N. A. (2014). Pengaruh Hijabers Community Terhadap Gaya Hidup Dan Keputusan Pembelian Hijab Pada Mahasiswa Fakultas Ekonomi Universitas Jember. E-Journal Ekonomi Bisnis Dan Akuntansi, 1(1), 67-71.

Yasin, F. (2015). Gaya Kehidupan Malam Remaja di Kota Padang; Suatu Kajian Subkultur di Tempat Hiburan Malam Kota Padang. Ilmu Sosial Mamangan, 2(1), 59-72. 